\title{
Diversity and Distribution of Benthic Macro Invertebrates in Ayiroor River, Kerala, South India
}

\author{
Ambili, $\mathbf{T}^{\mathbf{1}}$, Reenamole, G.R ${ }^{2}$ \\ Zoology Research Centre, Fatima Mata National College, Kollam, University Of Kerala, Thiruvananthapuram
}

\begin{abstract}
Macro benthic invertebrates fauna of Ayiroor River at Kerala, South India was conducted from February 2013 to January 2015. Ayiroor River is the smallest river in Southern Kerala lies between 8.75' N latitude and 76.71'E longitude an d drains an area of 66 Sqr.Km. Sediment samples were collected from three different stations along the river. A total of 312 individuals representing 4 taxa (insecta, oligocheates, bivalves and gastropods) and three phyla (Arthropoda, Mollusca and Annelida) were collected from the three stations of the river during the study period. Of these Arthropoda contributed the largest share constituting $70 \%$ of the total macrobenthic invertebrate fauna, followed by Mollusca, 22\% and Annelids 8\%.The textural analysis of the sediment showed that sand was the predominant fraction in all the stations followed by silt and clay. The presence of Chironomus larvae and Tubifex tubifex indicate the effect of pollution from anthropogenic sources, but not too much extent because of their low number in the study area. The water quality of the Ayiroor River was deteriorated by sewage effluents and agricultural activities, diminishing the abundance of benthic macroinvertebrates.
\end{abstract}

Keywords: Benthic Macro-Invertebrates, Chironomus Larvae, Tubifex Tubifex, Ayiroor River

\section{Introduction}

Benthic macro-invertebrates fauna are those organisms that live on or inside the deposit at the bottom of a water body (Idowu and Ugwumba, 2005). These organisms play a vital role in the circulation and recirculation of nutrients in aquatic environments. They constitute the link between the unavailable nutrients in detritus and useful protein materials in fish. Macro benthic invertebrate are biological quality element require for the classification of biological status of the water bodies [Imevbore et al., 1970]. According to Danes and Hynes (1980), occurrence and distribution of macro-invertebrate are governed mostly by the physical and chemical quality of water and immediate substrate of occupation. Macro-invertebrates play an important role in aquatic community which includes mineralization, mixing of sediments and flux of oxygen into sediment, cycling of organic matter and also in assessing the quality of inland water (George et al., 2009). The distribution of macro invertebrate fauna is determined by a number of factors such as the physical nature of the substratum, depth, nutritive content, degree of stability and oxygen content of the water body.Macro-invertebrate organisms are threatened by changes in their habitat which are associated with pollution, erosion and siltation (Lydeard et al., 2004).The use of macro-invertebrate diversity for bio-assessment provides a simpler approach and this is due to the fact that they can be sampled quantitatively as well as the known relative sensitivity or tolerance of some of them to contamination (Adakole and Annune, 2003). Species vary in their degree of tolerance with the result that under polluted conditions, a reduction in species diversity is the most obvious effect (Edokpayi et. al., 2000).

Biological indicator use in monitoring programs provides a more exact measure of anthropogenic effects on aquatic ecosystems and have the advantage of monitoring water quality over a long period of time, thus providing a more adequate picture of level of pollutant effects on the ecosystem than is the case for chemical methods, which provide only momentary evidence of water quality (Tundisi and Barbousa, 1995) .Within the organisms commonly used as biological indicators, benthic invertebrates stand out as ideal due to relatively low mobility and long life cycles, reflecting temporal patterns and local conditions; high diversity; abundance and consequently in providing a wide range of responses to different environmental pollution agents; large size and easy identification at high taxonomic resolution by non-specialists; well standardized and low cost methodologies; and temporal and spatial stability, reflecting changes in ecosystem processes.

Kerala, the land of rivers has a cultural history, which indeed is closely intertwined with the river valley social life. It is the land of 44 rivers, 41 of them flowing westwards joining the Lakshadweep Sea and 3 others flowing eastwards and joining the Bay of Bengal. The rivers of Kerala are small whether considered in terms of length, breadth or annual stream flow and majority of them are a receptacle for pollutants. Ayiroorpuzha, one of the smallest rivers of Kerala is about $17 \mathrm{~km}$ in length, originates in Navayikulam and flows through Thiruvananthapuram district in to the Edava- Nadayara Kayal. This study provides a baseline data on the composition, distribution, abundance and diversity of macro benthic invertebrates of Ayiroor River.

\section{Materials and Methods}

\subsection{Study Area}

Ayiroor River (8.75'N\&76.71'E) -The state of Kerala (Latitude 8018'N-12048'N and Longitude 14052'E-7702'E) is bordered on the east by the Western Ghats protecting it from the dry winds of the eastern plains of the subcontinent and on the west by the Arabian Sea. Even though there are 44 rivers in Kerala state, there are no existing studies on macro invertebrate diversity and water quality in Ayiroor River. 


\section{International Journal of Science and Research (IJSR) ISSN (Online): 2319-7064 \\ Index Copernicus Value (2013): 6.14 | Impact Factor (2014): 5.611}

Ayiroor River is the smallest rivers of Kerala, lies between $8.75^{\prime} \mathrm{N}$ latitude and 76.71 ' $\mathrm{E}$ longitude. It is about $17 \mathrm{Km}$ in length and drains an area of 66 Sqr.Km. It is the smallest river in southern Kerala and it originate from Vilangara in Navayikulam, flowing through Thiruvananthapuram district and empties in to the Edava- Nadayara Kayal. The average annual rainfall and stream flow are $2200 \mathrm{~mm}$ and $1324 \mathrm{~mm}^{3}$ respectively. It is one of the few rivers in Kerala free from any dam or reservoir. In its course it receives a variety of domestic wastes and agricultural effluents, which may lead to deterioration in the quality of water. The consequences are of increasing concern to ecologists, environmental managers and other interest groups.

Three stations (Station I-Panayara, Station2 -Ayiroor and Station 3-Nadayara) were selected along the stretch of the river from upstream to downstream for the present study. Based on the intensity and duration of rainfall, the period of study was divided into three seasons -Pre monsoon (February to May) Monsoon (June to September) and Post monsoon (October to January).

\subsection{Analysis of sediment}

Sediment temperature was measured using mercury filled Celsius Thermometer with an accuracy of $0.1^{\circ} \mathrm{C}, \mathrm{P}^{\mathrm{H}}$ by a digital $\mathrm{P}^{\mathrm{H}}$ Pen and texture by pipette analysis (krumbein and Pettyjohn, 1938)

Table 1: Seasonal diversity and distribution of benthic macro invertebrates of Ayiroor River, Kerala

\begin{tabular}{|c|c|c|c|c|c|c|c|c|c|}
\hline \multirow{2}{*}{$\begin{array}{c}\text { Benthic macro } \\
\text { invertebrate species }\end{array}$} & \multicolumn{9}{|c|}{ Seasons } \\
\cline { 2 - 13 } & \multicolumn{3}{|l}{ Premonsoon } & \multicolumn{3}{|c|}{ Monsoon } & \multicolumn{3}{c|}{$\begin{array}{c}\text { Post } \\
\text { monsoon }\end{array}$} \\
\cline { 2 - 13 } & S1 & S2 & S3 & S1 & S2 & S3 & S1 & S2 & S3 \\
\hline Chironomous larvae & + & + & + & + & + & - & + & + & + \\
\hline Dragonfly larvae & + & - & + & + & - & + & + & - & + \\
\hline Damsfly nymph & + & - & + & + & - & + & - & + & + \\
\hline Caddis fly larvae & + & + & + & + & + & - & + & - & + \\
\hline Potamia species & + & + & + & + & - & + & + & + & + \\
\hline Polymorphan species & - & + & + & + & - & + & + & + & - \\
\hline Baetis tricaudatus & + & - & + & - & + & + & + & + & + \\
\hline Habrophlebiodes & + & + & + & + & + & + & + & - & + \\
\hline species & & & & & & & & & \\
\hline Megaglena species & + & + & + & + & - & + & + & + & + \\
\hline mayfly nymphs & + & - & + & - & - & + & + & + & - \\
\hline Stonefly nymph & + & - & + & + & - & + & + & - & + \\
\hline Dryops larvae & + & + & + & + & + & + & - & + & + \\
\hline Tubifex tubifex & + & + & + & + & + & + & + & + & + \\
\hline Viviparous bengalensis & + & + & + & - & + & - & + & + & - \\
\hline Melania tuberculata & - & + & + & + & - & - & - & - & - \\
\hline Umbonium vestarium & - & + & + & - & + & - & + & + & - \\
\hline Villorite cyprinoids & + & + & + & + & + & + & + & + & - \\
\hline Lamellidens marginalis & - & + & + & - & + & - & - & + & - \\
\hline
\end{tabular}

\subsection{Analysis of fauna}

The sediment samples preserved in $4 \%$ formalin were sieved through $0.5 \mathrm{~mm}$ mesh.The organisms visible to the naked eye were sorted and counted during the initial washing. The materials retained were preserved in 5\% formalin, and stained with Rose Bengal for further sorting and identification.

\section{Results and Discussion}

\subsection{Sediment Temperature}

Sediment temperature varies with the temperature of the water overlying it and the atmospheric temperature. Maximum mean temperature was recorded at station 2 $\left(23.8 \pm 0.85^{\circ} \mathrm{C}\right)$ and minimum at station $3\left(23.67 \pm 0.82^{\circ} \mathrm{C}\right)$.

\subsection{Sediment $\mathbf{P}^{\mathbf{H}}$}

$\mathrm{P}^{\mathrm{H}}$ is an important ecological factor in riverine system. Maximum $\mathrm{P}^{\mathrm{H}}$ was recorded at station I $(6.13 \pm 0.43)$ and minimum at station $2(6.07 \pm 0.22)$.

\subsection{Sediment Texture}

The average value of sand was maximum at station 1 and 2 (54.5\%), silt at station $1(39.5 \pm 2.69 \%)$ and clay at station $3(8.5 \pm 0.71 \%)$. Minimum value of sand $(54.2 \%)$ and silt $(38 \pm 1.87 \%)$ were recorded in station 3 and clay in station $1(6 \pm 0.71 \%)$. The range of variation of sand, silt and clay were $0.3 \%, 1.5 \%$ and $2.5 \%$ respectively. Sand was the predominant fraction of sediment in all the stations followed by silt and clay.

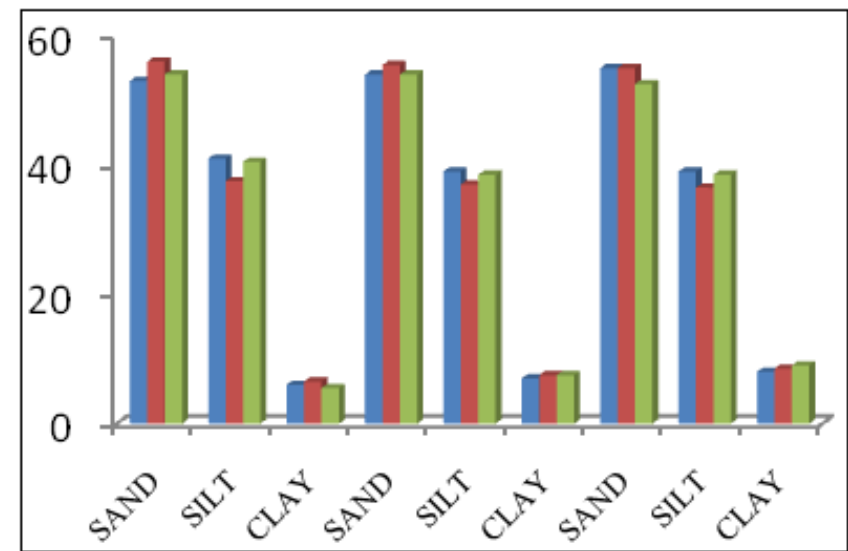

Figure 1: Mean value of seasonal variation in sediment texture of Ayiroor River, Kerala

\subsection{Qualitative analysis of benthic macro invertebrates}

Analysis of macro benthos showed the presence of 12 species of Arthropoda belonging to the class Insecta (Chironomous larvae, dragon fly larvae, Damselfly nymph, Caddis fly larvae, Potamia species, Polymorphan species, Baetis tricaudatus, Habrophlebiodes species, Megaglena species, Mayfly nymph, Stonefly nymph and Dryops larvae ), 1 species of Annelida belonging to the class Oligocheates (Tubifex tubifex) and 5 species of Mollusca belonging to Bivalves (Villorita cyprinoids and Lamellidens marginalis) and Gastropods (Viviparous bengalensis, Melania tuberculata and Umbonium vestarium.

\subsection{Seasonal diversity and distribution of benthic macro invertebrates}

In station 1, a total of 117 individuals belonging to 18 species, 4 taxa (insecta, oligocheates, bivalves and 


\section{International Journal of Science and Research (IJSR) ISSN (Online): 2319-7064 \\ Index Copernicus Value (2013): 6.14 | Impact Factor (2014): 5.611}

gastropods) and 3 phyla (Arthropoda, Mollusca and Annelida), in station 2, a total of 110 individuals belonging to 18 species ,4 taxa (insecta, oligocheates, bivalves and gastropods) and 3 phyla (Arthropoda, Mollusca and Annelida) and in station 3, a total of 85 individuals belonging to 18 species, 4 taxa (insecta, oligocheates, bivalves and gastropods) and 3 phyla (Arthropoda, Mollusca and Annelida) were recorded. In station 1 and 2 pre phyla (Arthropoda, Mollusca and Annelida) and in station 3, a total of 85 individuals belonging to 18 species, 4 taxa (insecta, oligocheates, bivalves and gastropods) and 3 phyla (Arthropoda, Mollusca and Annelida) were recorded. In station 1 and 2 pre monsoon (14 species) and post monsoon (13 species), accounts for maximum diversity of benthic macro invertebrates and monsoon the minimum, 13 and 10 species respectively. In station 3, pre monsoon accounts for maximum diversity (18 species) followed by monsoon (12 species) and post monsoon (11 species).

\subsection{Seasonal Abundance (\%) of Benthic Macro Invertebrates}

A total of 312 individuals representing 4 taxa (insecta, oligocheates, bivalves and gastropods) and three phyla (Arthropoda, Mollusca and Annelida) were collected from the study area .Of these Arthropoda contributed the largest share constituting $70 \%$ of the total macro-benthic invertebrate fauna, followed by Mollusca (22\%) and Annelids (8\%) respectively. Among Arthropods, chironomous was the dominant species and it contributed $15.7 \%$ of the total Arthropod population. Villorita cyprinoids was the second dominant species (9.6\%), followed by Tubifex tubifex (7.7\%), then Dryops larvae (7.4\%) and least was the Melania tuberculata which represented $1.6 \%$ of total Arthropods. Among Molluscs, Villorita cyprinoids was the dominant species and it contributed $9.6 \%$ of total Molluscan fauna collected Tubifex tubifex was the only species representing phylum Annelida, which contributes $7.7 \%$ of the total species collected from the study area. The order of numerical abundance of macro benthic fauna of different sites are S1 (117)>S2 (110)>S3 (85).from the study area, followed by Umbonium vestarium $(4.5 \%)$ and least was the species Melania tuberculata (1.6\%).

\subsection{Relative abundance and Species composition of benthic macro invertebrates}

In all stations the relative abundance of class insecta was maximum (92\% in station1, 48\% in station 2 and $85 \%$ in station3) followed by bivalves in station 1 (11\%) and $2(23 \%)$ and gastropods in station 3(5\%). Oligocheates accounts for minimum relative abundance in all the stations i.e. $5 \%$ in station $1,14 \%$ in station 2 , and $4 \%$ in station 3 .

$\square$ Insecta $\square$ Oligocheates $\square$ Gastropods $\square$ Bivalves

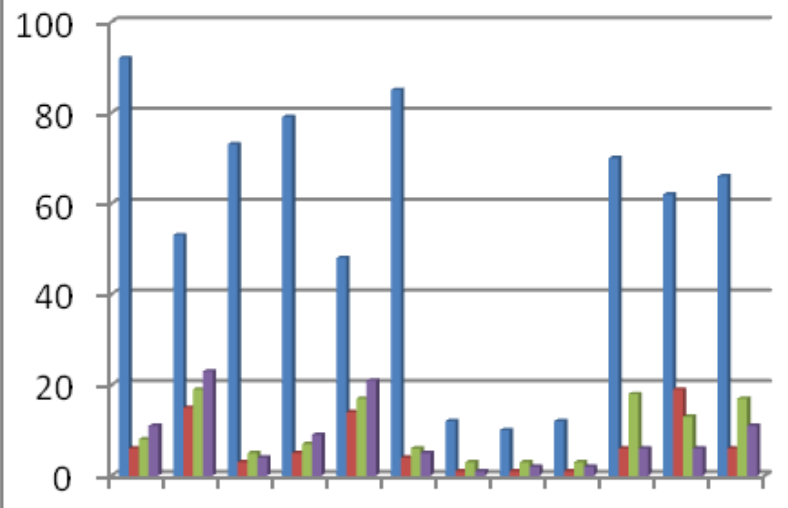

S1 S2 S3 S1 S2 S3 S1 S2 S3 S1 S2 S3

Figure 2: Relative abundance and species composition of benthic macro invertebrates in Ayiroor River

In all stations class insecta dominates with maximum species composition ( $70 \%$ at station $1,62 \%$ at station 2 and $66 \%$ at station 3). In station 1 oligocheates and bivalves accounts for minimum species composition (6\%).In station 2 bivalves and in station 3 oligocheates shows species composition with a minimum of $6 \%$.

\subsection{Diversity score of benthic macro invertebrates}

Diversity score is the ratio of the total number of species and the total number of organisms encountered. At station1 diversity score was maximum during monsoon (0.41) and minimum during pre monsoon (0.31), at station 2 it was maximum during post monsoon (0.34) and minimum during pre monsoon (0.31) and at station 3 it was maximum during monsoon (0.52) and minimum during post monsoon (0.42)

Table 2: Relative abundance and species composition of benthic macro invertebrates in Ayiroor River

\begin{tabular}{|c|c|c|c|c|c|c|c|c|c|c|c|c|}
\hline \multirow{2}{*}{\begin{tabular}{|c|} 
Macro \\
invertebrate taxa \\
\end{tabular}} & \multicolumn{3}{|c|}{ Total number of individuals } & \multicolumn{3}{|c|}{ Relative abundance (\%) } & \multicolumn{3}{|c|}{ Total number of species } & \multicolumn{3}{|c|}{ Species composition (\%) } \\
\hline & S1 & S2 & S3 & S1 & S2 & S3 & S1 & S2 & S3 & S1 & S2 & S3 \\
\hline Insecta & 92 & 53 & 73 & 79 & 48 & 85 & 12 & 10 & 12 & 70 & 62 & 66 \\
\hline Oligocheates & 6 & 15 & 3 & 5 & 14 & 4 & 1 & 1 & 1 & 6 & 19 & 6 \\
\hline Gastropods & 8 & 19 & 5 & 7 & 17 & 6 & 3 & 3 & 3 & 18 & 13 & 17 \\
\hline Bivalves & 11 & 23 & 4 & 9 & 21 & 5 & 1 & 2 & 2 & 6 & 6 & 11 \\
\hline Total & 117 & 110 & 85 & 100 & 100 & 100 & 17 & 16 & 18 & 100 & 100 & 100 \\
\hline
\end{tabular}

\section{Conclusion}

The present study shows that the macro benthic composition and abundance varied among stations and had an increasing trend from downstream to upstream. The species composition of benthic macro fauna in the present investigation shows the dominance of Arthropoda followed by Mollusca and Annelida. The most abundant macro benthic invertebrate fauna throughout the study period was Chironomus larvae. The reason for this phenomenon may be attributed to the fact that this insect is known to thrive in polluted environment due to the possession of haemogloblin, 


\section{International Journal of Science and Research (IJSR) \\ ISSN (Online): 2319-7064 \\ Index Copernicus Value (2013): 6.14 | Impact Factor (2014): 5.611}

a pigment that transport and store dissolved oxygen. Chironomous larvae showed its peak during monsoon. The presence of the pollution indicators species chironomous and tubifex in all the stations and seasons, shows that the water in this stretch of the river is polluted primarily due to anthropogenic activities.

\section{References}

[1] JA Adakole and PA Anunne, 2003. Benthic macro invertebrates as indicators of environmental quality of an urban stream, Zarie, Northern, Nigeria. J Aquat. Sc. 18 (2), 85-92

[2] KW Danes and HBN Hynes, 1980. Some effects of agricultural land use on stream insect communities. Environ. Pollut. Ser, 22, 19-28.

[3] C A Edokpayi, J C Okenyi, A E Ogbeibu and EC Osimen, 2000. The effect of human activities on the macro benthic invertebrates of Ibiekuma Stream, Ekpoma, Nigeria. Biosci. Res.Commun, 12: 79-88.

[4] ADI George, JFN Abowei and ER Daka, 2009. Benthic Macro Invertebrate Fauna and Physicochemical Parameters in Okpoka Creek Sediments, Niger Delta. Nigeria International Journal of Animal and Veterinary Advances, 1(2), 59-65.

[5] EO Idowu and A Ugwumba, 2005. Physical, chemical and benthic faunal characteristics of a Southern Nigeria Reservoir. The Zoologist, 15-25

[6] AM Imevbore and O Bakare, 1970.Ed. Studies, 7, 8798.

[7] C Lydeard, RH Cowie, WF Ponder, AE Bogan and P Bouchet, 2004 .The global decline of Non- marine mollusks. Bioscience, 54: 321-330

[8] EP Odum, 1971. Fundamentals of ecology, 3rd W.B. Saunders Company. Philadelphia, pp. 574.

[9] AE Ogbeibu and Egborge, 1995. ABM Trop. Freshwater Biol, 4, 1-27.

[10] H Timm and T Mois, 2008. Verh. Int. Verein. Limnol, 30, 138-140.

[11] JTyokumbur TG Okorie and OA Ugwumba, 2002. The Zoologist, 1, 59-69

[12] W.C Krumbein, and Pettijohn, 1938. Manual of sedimentary petrography, Appleton -Century Crafts, New York 549.

\section{Author Profile}

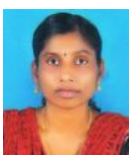

Ambili. T received the B.Sc. degree in Zoology from Sree Narayana Womens College, kollam. B.Ed in Natural Science from Kerala University Teacher Education Centre,Govt.Boys H.S.S,Kollam and M.Sc. degree in Zoology from Fatima Mata National College, Kollam. She awarded SET and taken DCA. M. Phil in Aquatic Biology and Fisheries from the Department of Aquatic Biology \& Fisheries in the University of Kerala, Kariavattom in 2012. All the degrees were received from the University of Kerala, Thiruvananthapuram, India. She has published 14 research papers. She now is doing Ph.D in Zoology at Zoology Research Centre, Department of Zoology, Fatima Mata National College, Kollam, University of Kerala, India.
Anchal College, Kollam. M.Sc. degree in Zoology from Mahatma Gandhi College, Trivandrum. M. Phil in Aquatic Biology and Fisheries from the Department of Aquatic Biology \& Fisheries in the University of Kerala, Kariavattom in 2012. All the degrees were received from the University of Kerala, Thiruvananthapuram, India. She has published 14 research papers and designed a text book of "Vellayani Fish Census- a Field Guide and Report" (Author : Dr. A. Biju Kumar \& Dr. Pramod Kiran R.B) published by Dept. of Aquatic Biology and Fisheries, University of Kerala and Supported by Agency of Development of Aquaculture, Kerala (ADAK) 2013. During 2008-2009, she worked as a Project Fellow in Central Marine Fisheries Research Institute in Vizhinjum, Thiruvananthapuram, Kerala, India. She now is doing Ph.D in Zoology at Zoology Research Centre, Department of Zoology, Fatima Mata National College, Kollam, University of Kerala, India.

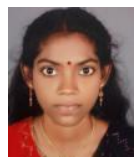

Reenamole.G.R received the B.Sc. degree in Zoology from H.H.M.S.P.B.N.S.S.College for Women, Neeramankara. B.Ed in Natural Science taken from Govt. 